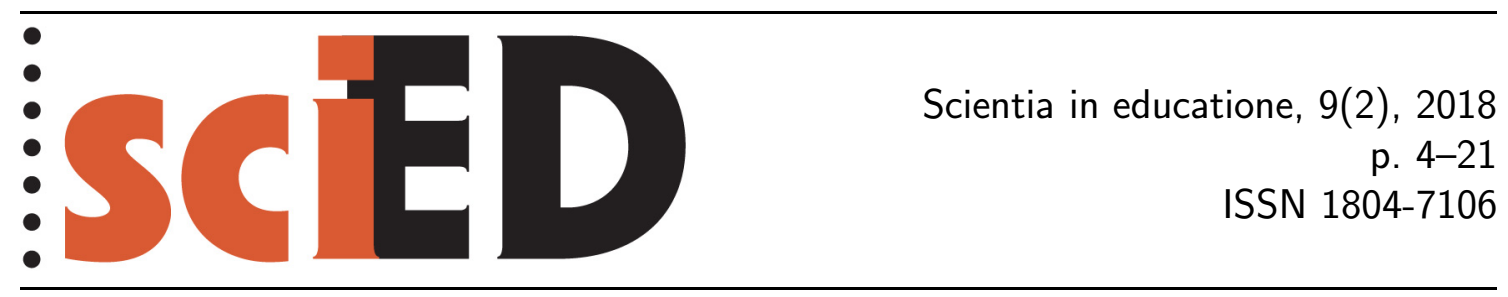

\title{
Vizuálie v geografickém vzdělávání: přehledová studie
}

\author{
Tomáš Janko, Petr Knecht, Silvie Rita Kučerová, Jan Daniel Bláha
}

\begin{abstract}
Abstrakt
Příspěvek objasňuje, jak mohou být poznatky o učení se z obrazového materiálu využity s ohledem na požadavek zlepšování kvality výukových materiálů v geografickém vzdělávání. Cílem narativní přehledové studie je zjistit: a) jak je možné učení se ze zpracování vizuálních geografických informací teoreticky ukotvit, b) jak je možné operacionalizovat geografické vizuálie pro potřeby zkoumání školní výuky zeměpisu/geografie a pro potřeby tvorby učebnic a atlasů, c) zda je možné na základě zmapování dosavadního stavu poznání identifikovat oborově specifická doporučení umožňující srozumitelnou a žákům blízkou statickou vizualizaci geografických jevů. Metodický přistup vychází z rešerše odborné literatury spadající do oblasti kognitivní psychologie a pedagogických věd. Výzkumná zjištění se následně snažíme rozpracovat pro potřeby geografického vzdělávání. V poslední části studie se zamýšlíme, jak mohou být získané poznatky využity ke zlepšování kvality vizuálních prostředků v geografickém vzdělávání.
\end{abstract}

Klíčová slova: geografické vzdělávání, didaktika geografie, vizuálie, vizualizace, vizuální prostředky.

\section{Visuals in Geography Education: A Review}

\begin{abstract}
The study seeks to explain how evidence-based knowledge about learning from visual material can be utilized by way of improving the visuals used in geography education. The aim of this narrative review is to find out: a) the theoretical foundations of learning from visuals, b) how to operationalize geographical visuals in a way that would facilitate research on school instruction and inform the production of textbooks and atlases, c) to identify (based on the state of the art) some domain specific recommendations contributing to more understandable and pupil-friendly static visualization of geographical phenomena. The methodology is based on the review of literature related to the domains of cognitive psychology, educational science, and geography education. In the concluding part, it is suggested how the findings of our study may contribute to the improvement of visuals in geography education.
\end{abstract}

Key words: geography education, didactics of geography, visuals, visualisation. 
Vizuální kultura a vizuální komunikace nabývají v kontextu běžného života stále většího významu (Jewitt, 2008). Někteří autoři hovoří o tzv. vizuálním obratu (viz např. Benedek \& Nyíri, 2012). Jsou to právě vizuálie, které nás v běžných životních situacích, například reklama apod., ovlivňují a formují (Taussig, 2011). Vzrůstá společenská potřeba analyzovat, jak se vizuální obrat projevuje v různých oblastech lidské kultury, a školní vzdělávání není výjimkou. V kontextu školního vzdělávání se v souvislosti s narůstajícím významem vizuální kultury pracuje s termínem vizuální gramotnost (angl. visual literacy). Vizuální gramotnost představuje jeden z nadoborových cílů vzdělávání a je možné ji definovat jako soubor dovedností umožňující správně interpretovat a tvořit vizuální informace (Gates, 2004: s. 223). Cílem je, aby byl žák schopen multimodální komunikace, tj. komunikace umožňující pohyb mezi různými módy sdělování obsahu. Přestože význam vizuální informace ve školní výuce kontinuálně vzrůstá (Jewitt, 2008; Rose, 2007 aj.), jejich praktickému využití ve školní výuce je výzkumná pozornost věnována pouze v omezené míre.

Učení se z obrazového materiálu má svůj základ ve zpracování vizuálních informací. Ačkoli se dosavadní stav poznání týkající se učení se z obrazového materiálu může na první pohled jevit jako robustní (souhrnně viz Mareš, 2013a: s. 129-154), objevují se ve vědecké literatuře poměrně významné mezery. Unwin (2008: s. XV) upozorňuje na absenci dostatečně fundovaných teorií, které by umožňovaly zodpovědět, jaké formy vizualizace fungují, za jakých okolností, případně naznačily nejvhodnější způsob vizuálního zobrazení vzhledem k specifické povaze zobrazovaných jevů. Autorům předkládaného příspěvku nejsou známy žádné oborově specifické teorie, týkající se didaktického využití obrazového materiálu ve výuce jednotlivých oborů zastoupených ve škole. Tento poznatkový nedostatek je zvláště markantní v oblasti tzv. všeobecně vzdělávacích předmětů. Popsaný problém se snažíme v této studii překlenout tím, že se pokoušíme dostupné poznatky kotvené zejména $\mathrm{v}$ diskursu kognitivní psychologie a obecných pedagogických věd aplikovat se zvláštním zřetelem $\mathrm{k}$ potřebám rozvíjení poznatkové základny didaktiky geografie a geografického vzdělávání. Nedostatek informací a syntéz vědecky ověřených poznatků, týkajících se výše zmíněných výzkumných problémů, se následně projevuje např́klad v nízkém nebo chybějícím překryvu mezi pedagogickými a psychologickými teoriemi a reálnou učebnicovou tvorbou (srov. např. Janko, 2012).

Vizuální média a technologie $\mathrm{v}$ geografii umožňují plnohodnotnou vizualizaci komplexních dat a poznatků (meteorologické modely, prognózy globálního oteplování, šǐření epidemií apod.). Různé formy vizuálií mají proto své místo také v geografickém vzdělávání. V předkládané studii se snažíme zodpovědět otázku, jak mohou být poznatky o učení se z obrazového materiálu využity s ohledem na požadavek zlepšování kvality statických forem vizuálií v geografickém vzdělávání.

\section{Metodologie}

Problematika vizuálních informací a jejich využití ve výuce geografie představuje aktuální, avšak poměrně komplexní výzkumnou oblast, v níž lze rozlišovat specifické výzkumné proudy využívající charakteristické výzkumné přistupy a metody. V tomto příspěvku se zaměřujeme na dílčí problém dané výzkumné oblasti. Za cíl jsme si stanovili zjistit: 
(a) jak je možné učení se ze zpracování vizuálních geografických informací teoreticky ukotvit;

(b) jak je možné operacionalizovat geografické vizuálie pro potřeby zkoumání školní výuky zeměpisu/geografie a pro potřeby tvorby učebnic a atlasů;

(c) zda je možné na základě zmapování dosavadního stavu poznání identifikovat oborově specifická doporučení umožňující srozumitelnou a žákům blízkou statickou vizualizaci geografických jevů.

S ohledem na charakter výzkumného problému je příspěvek koncipován jako narativní přehledová studie, pro niž je charakteristické teoretizování, vysvětlování, zdůvodňování a kritická reflexe použitých pramenů (Mareš, 2013b; viz také Davies, 2000).

Z dostupných zdrojů jsme se $\mathrm{v}$ přehledové studii zaměřili na výzkumné články v časopisech, které byly publikovány v angličtině. Za zdroj studií byly zvoleny mezinárodní publikační databáze (Scopus, Web of Science, ProQuest). Pro vyhledávání konkrétních studií byly zadávány kombinace termínů visuals, picture, visual representation a education (article title, abstract, keywords) a následně je $\mathrm{v}$ př́padě potřeby zpřesnili pojmy textbook nebo geography.

Celkem jsme pracovali s 91 publikacemi. Jelikož pouze jedna pětina prací získaných z databází (celkem 18 publikací) se jevila jako relevantní vzhledem ke stanoveným výzkumným otázkám, zařadili jsme do přehledu také související práce dohledané na základě materiálu získaného z prvního výběru (celkem 41 publikací). Jednalo se např. o odborné knihy, resp. kapitoly v knihách, případně publikace domácích autorů přinášející důležité informace $\mathrm{k}$ teoretickému pozadí problematiky vizuálních informací (např. vizualizace, vizuální gramotnost, iconic turn), či konkrétním otázkám souvisejícím s řešením problematiky v geografii (vizualita geografických jevů, kartografie jako klíčová metoda při zobrazování geografických jevů atd.).

Problematika vizuálií a jejich fungování ve školní výuce má mnohaletou tradici a probíhá na různých úrovních. Rozhodujícím kritériem výběru pro nás proto bylo věcné hledisko, výběr studií jsme tedy dále neomezovali z hlediska data publikace, sociokulturních podmínek, použitých postupů apod. Limitem námi zvoleného přístupu je zaměření pozornosti na studie vyskytující se v mezinárodních publikačních databázích.

$\mathrm{V}$ přehledové studii nejprve věnujeme pozornost nejčastěji aplikovaným teoretickým přístupům ke zkoumání procesu učení se z obrazového materiálu, následně popisujeme výzkumem doporučované charakteristiky vizuálií a obecná doporučení pro tvorbu vizuálií ve vzdělávání a následně přibližujeme poznatky týkající se operacionalizace a vymezení klíčových charakteristik geografických vizuálií.

\section{GEOGRAFICKÉ VIZUÁlie JAKO JEDNA Z CEST K VIZUÁLNÍ GRAMOTNOSTI}

Náš zájem a současně motivace $\mathrm{k}$ tvorbě předkládané přehledové studie také vyplývají z potřeb praxe. Práce s vizuální geografickou informací představuje na nižších stupních vzdělávání spíše ideál než běžnou výukovou praxi. Pro školní vzdělávání je charakteristická přetrvávající „rezervovanost“ vưči využívání vizuálních informací, nebot učitelé stále upřednostňují práci s verbálním (textovým) kanálem na úkor didaktického užití vizuálních reprezentací (Schnotz \& Bannert, 2003; Schnotz, 2002; 
Schnotz, 2014). ${ }^{1}$ To kontrastuje s teoriemi učení, které dokládají, že učení je efektivní zejména $\mathrm{v}$ případě, kdy je využíváno více smyslových kanálů. Zásadní je $\mathrm{v}$ tomto ohledu především využivání verbálního a vizuálního smyslového kanálu (srov. Sadoski \& Paivio, 2001; Mayer, 1997, 2014 aj.).

$\mathrm{S}$ přihlédnutím k výše uvedenému je žádoucí, aby geografické vzdělávání přispívalo $\mathrm{k}$ utváření a rozvíjení vizuální gramotnosti (definice viz výše). Jedná se o jeden z důležitých cílů geografického vzdělávání, nebot geografické znalosti by měly být utvářeny s využitím map a plánů, fotografií, obrázků, schémat, náčrtů, posterů, grafů a jiných typů vizuálních reprezentací. Právě zde spatřujeme klíčovou roli vizuální geografické informace, představující specifický druh vizuální informace, který může být transformován prostřednictvím geografických vizuálií.

Geografické vizuálie chápeme jako vnější obrazové reprezentace zahrnující širokou škálu materiálio, jež umožňují v různé formě sdělovat, nést vizuální geografickou informaci. Tyto vizuálie tedy umožňují znázorňovat geografické jevy a data v různé míře abstraktnosti (resp. zobecnění). Míra abstraktnosti souvisí s použitým typem vizuálie (Ballstaedt, 1997). Vizuálie ovlivňují vnímání, uvažování i jednání týkající se kulturních, sociálních, politických i vzdělávacích aspektů geografických jevů. V obecné rovině můžeme konstatovat, že geografické vizuálie jsou výsledkem geovizualizace, kterou vymezujeme jako využívání grafických metod, jež napomáhají porozumět geografickým jevům, procesům, podmínkám nebo konceptům a jejich prostorovým aspektům (Dodge, McDerby \& Turner, 2008: s. 2).

\section{VIZUÁLIE VE VZDĚLÁVÁNÍ: TEORETICKÉ PŘÍSTUPY}

Předtím, než přistoupíme k operačnímu vymezení geografických vizuálií, považujeme za nezbytné představit nejčastěji aplikované teoretické přístupy ke zkoumání procesu učení se z obrazového materiálu. Ty jsou založeny na rozlišování senzorických kanálů, např. sluchový/vizuální, anebo různorodých modů reprezentací, např. textové/obrazové, a také předpokladu omezené kapacity pracovní paměti učícího se jedince (McTigue \& Coleman, 2013: s. 285-290; srov. také Mareš, 2013a: s. 131-133). Z uvedených principo̊ vychází zejména teorie duálního kódování, kognitivní teorie multimediálního učení, teorie kognitivní zátěže a teorie obrazu, kterým se níže věnujeme podrobněji.

\subsection{TEORIE DUÁLNíHO KÓDOVÁNí}

Teorie duálního kódování (např. Paivio, 1971; 2014) předpokládá, že verbální (textové) a nonverbální (obrazové) informace jsou v lidské mysli zpracovávány odlišným způsobem. Verbální systém je založen na práci s lingvistickými jednotkami (logogeny), umožňuje detailnější, ale sekvenční zpracování jazykových informací. Nonverbální systém operuje s generátory obrazu (imageny) a využívá paralelních simultánních procesů, čímž umožňuje uchopit celkovou strukturu zprostředkovávané skutečnosti najednou (prostorovou a synchronní informaci). I když informace může být zpracována jen jedním z kanálı̊, z hlediska učení je optimální, pokud je informace zpracovávána paralelně oběma kanály. Propojování mezi slovními spojeními a vizuálními analogiemi totiž napomáhá začleňování nových informací do stávajících kognitivních struktur.

\footnotetext{
${ }^{1}$ Jistou výjimku patrně představuje práce s mapou. Přestože robustní výzkumy výuky zeměpisu chybí, výzkumné sondy naznačují, že se mapa ve srovnání s ostatními typy vizuálií vyskytuje ve školní výuce zeměpisu v relativně vyšší míře (srov. Hübelová, Najvarová \& Chárová, 2008).
} 


\subsection{Kognitivní teORIE MULTimediÁlníHo UČENí}

Kognitivní teorie multimediálního učení (např. Mayer, 2011) předpokládá, že existují dva kanály - verbální a vizuální, z nichž každý zpracovává příslušné druhy informací. Senzorická pamět zaznamenává verbální a vizuální podněty, pracovní pamět dočasně tyto podněty krátkodobě uchovává, př́ipadně s nimi manipuluje. Má však omezenou kapacitu. Dlouhodobá pamět informace ukládá. Tištěná slova jsou v pracovní paměti nejprve zpracována v obrazovém kanálu a následně jsou přesunuta do verbálního kanálu. Následně dojde k integrování verbálních a obrazových reprezentací s relevantními předchozími znalostmi. Kritickým faktorem z hlediska učení nebo porozumění zpracovávané informaci je tedy to, zda kognitivní náročnost zprostředkovávané informace nepřekročí kapacitu pracovní paměti. Výsledkem by mělo být uložení poznatku v dlouhodobé paměti. Pokud by učící se jedinec využíval pouze jeden z dostupných kanálů (jen verbální nebo jen vizuální), existuje důvodný předpoklad, že dosáhne horších výsledků (viz dále).

\subsection{TEORIE KOGNITIVNí ZÁTĚŽE}

Teorie kognitivní zátěže (např. Sweller, 1988) vychází z předpokladu, že má-li být učení efektivní, mělo by být organizováno v souladu se zákonitostmi lidského kognitivního systému. Ústředním principem teorie je součinnost mezi senzorickou, pracovní/krátkodobou a dlouhodobou úrovní lidské paměti. Zde dochází ke zpracovávání vnějších podnětů a jejich reorganizaci do kognitivních schémat. Ta jsou následně transformována do dlouhodobé paměti - poznatkových struktur. Podstatné je, že kapacita krátkodobé paměti má své limity, zatímco kapacita dlouhodobé paměti je relativně neomezená. Efektivita tohoto procesu může být ovlivněna také kvalitou logických vazeb mezi osvojovanými informacemi různé modality. Edukační materiály by proto měly být koncipovány tak, aby napomáhaly ke snižování kognitivní zátěže potřebné pro osvojení, resp. porozumění určitému vzdělávacímu obsahu prostřednictvím eliminace efektu rozdělení pozornosti (informace prezentované různými smyslovými kanály nejsou vzájemně provázány), efektu redundance (edukační materiál obsahuje nadbytečné informace) a efektu modality (informace nejsou prezentovány s ohledem na využití více smyslových kanálů (např. verbálním a vizuálním).

\subsection{TEORIE OBRAZU}

Teorie obrazu (Aumont, 2011) vychází především z diskursu moderní sémiotiky (Peirce, 1997; de Saussure, 1916; Eco, 1976) a spočívá zejména v analýze vztahu recipienta vizuálie a samotné vizuálie a posuzuje kvalitu přenosu vizuální informace mezi nimi. Efektivnost a kvalita vizuálie je podmíněna myšlenkovým propojením zprostředkovávané reprezentace a reálného jevu, což vyžaduje fungování vztahu mezi znakem (sign) a objektem (princip denotace). Zásadní pro porozumění geografickým jevům, procesům a konceptům s využitím geografických vizuálií je ovládnutí specifického systému symbolů a zobrazovacích konvencí (Radinsky, Leimberer \& Rodriguez, 2013: s. 240-241; Koláčný, 1969 aj.). ${ }^{2}$ To koresponduje i s Aumontovou

\footnotetext{
${ }^{2}$ Ačkoliv první snahy o jazykovou koncepci mapy, typické geografické vizuálie, pocházejí již z padesátých let 20. století (např. Wooldridge \& East, 1951), za průkopníka kartografické sémiologie, tedy disciplíny, která se zabývá kartografickými znaky, jejich vlastnostmi, tříděním apod. a na tyto znaky pohlíží jako na lingvistický systém, je považován J. Bertin (1967). Zavedl šest tzv. grafických proměnných kartografického znaku, přičemž tyto proměnné mají dále pět charakteristik. Výsledkem je 63 relevantních kombinací (jakási abeceda), které tento specifický grafický systém poskytuje k popsání geografické reality.
} 
(2011) zmínkou o klíčové roli kompetence recipienta obrazu. Vyjdeme-li z pojmu „vizuální komunikace“, pak má každá „vizuální informace“ tř̌i úrovně sdělení: frame message (rámcové poselství o tom, že sdělení je sdělení - uživatel pozná, že se jedná o mapu/graf, nikoli o náhodný shluk čar a ploch), outer message (vnější poselství o tom, jak má uživatel danou vizuálii dekódovat, tedy číst) a inner message (vnitřní poselství o významu obsahu, tedy jaké území je v mapě zobrazeno, jaké jsou vztahy mezi znázorněnými objekty a jevy, které konkrétní údaje graf nese atd.). Vyšší kvality recepce některých typů vizuálií lze například dosáhnout vytvořením vyváženého počtu jejích „rovin“ (v mapě jsou to např́iklad roviny popis - figurální - liniové plošné prvky mapového obsahu tvořící pozadí), dále též použitím takových vyjadřovacích prostředků, které se postupem času staly vžitými a zároveň podporují vlastnosti její použitelnosti, tj. jsou názorné, přehledné, čitelné atd. Přeneseno na geografické vzdělávání: kupříkladu při používání mapy je nezbytné rozumět mapovému jazyku, vyjadřovacím prostředkům mapy a principům zobrazování reality prostřednictvím mapy, tj. porozumění zobrazovacímu systému, pak teprve lze poznávat a rozlišovat objekty a jevy v mapě zobrazené.

\subsection{TEORETICKÉ Př́́STUPY: SHRNUTÍ}

Výše uvedené teorie sloužily jako východisko pro realizaci mnoha výzkumů. Mayer (2011: s. 432) odkazuje na třináct experimentálních studií, které ukazují, že zkoumané osoby dosáhly lepších výsledků, když se učily z tištěného textu doplněného obrázky, než osoby, které se učily pouze z tištěného textu. ${ }^{3}$ Patrně na obdobném empirickém základě formulovali Spiro a Jehng (1990) teorii kognitivní flexibility, která ř́iká, že schopnost žáka přepínat mezi různými reprezentacemi v př́íslušné obsahové doméně podporuje učení.

Cílem využití vizuálií ve vzdělávání nicméně není pouze pasivní pozorování vizuálního zobrazení, vedoucí obvykle k reprodukování již známých skutečností (dokumentace či ilustrace pomocí vizuálie), nýbrž aktivní interagování s elementy (náročnější učební úlohy s vizuáliemi) a výrazovými prostředky příslušného vizuálního prvku vedoucí objevování dosud neznámých skutečností. Z uvedeného vyplývá, že vizuální reprezentace, které přispívají ke snižování kognitivní zátěže u žáků s nízkou úrovní dosavadních znalostí, nemusejí být zároveň přínosné pro žáky s bohatými znalostmi a zkušenostmi. Výzkumy dokládají, že experti dosahují lepších výsledků, v rovině zapamatování faktů i na úrovni hlubšího porozumění zobrazovaných skutečností, když jsou jim vybrané informace předkládány bud' pouze ve formě tištěného textu nebo pouze ve formě vizuálie. Oproti tomu začátečníkům pomáhá, když se mohou př́śslušnou informaci učit z materiálů, kde je text současně doprovázen vizuálními prvky. Je to patrně proto, že začátečníci, případně žáci s nižší kognitivní kapacitou, se zaměřují pouze na povrchové struktury problému (Chi, Feltowich \& Glaser, 1981; Wainer, 1992). Pokud nahlédneme výzkumná zjištění z kritického úhlu pohledu, ukazuje se, že poznatky a teorie, které jsou k dispozici, jsou zpravidla př́liliš obecné (Rose, 1994: s. 282), tj. nebyla ověřena jejich platnost např́ič vzdělávacími doménami a současně napřič různými formami vizuálií.

\footnotetext{
${ }^{3}$ Oproti tomu Ainsworthová (2006: s. 187) s odkazy na jiné výzkumy uvádí, že výzkumy př́inosnosti současného používání více typů reprezentací při učení jsou neprůkazné.
} 


\section{VIZUÁliE VE VZDĚLÁVÁNÍ: KLÍČOVÉ CHARAKTERISTIKY A DIDAKTICKÉ SOUVISLOSTI}

V následující kapitole opouštíme doménu kognitivně psychologických teorií a zaměřujeme se na generické vlastnosti/charakteristiky didaktických vizuálií, případně na interakci vizuálií a učícího se jedince.

Schnotz (2002) rozlišuje deskriptivní (symbolické) reprezentace a depiktivní (ikonické reprezentace). Zatímco depiktivní reprezentace jsou nejvíce využitelné pro zobrazování jednoduše viditelných informací, deskriptivní reprezentace umožňují zobrazovat také abstraktní nebo složitější informace. Ainsworthová (2006: s. 184) dále uvádí, že v př́ipadě vícečetných reprezentací je možné posuzovat jejich následující dimenze:

1. počet (mohou být dvě, ale i více reprezentací, někdy ale zcela stačí pouze jedna reprezentace);

2. způsob distribuce informace (osciluje mezi dvěma extrémy - prezentováním redundantní informace a prezentováním naprosto odlišných informací jednotlivými formami reprezentací);

3. forma systému reprezentací/typ (obrázky, text, grafy, ... );

4. pořadí reprezentací (reprezentace mohou být předkládány současně nebo postupně);

5. podpora translace (přechodu, převodu - angl. translation) mezi reprezentacemi.

Různé typy vizuálií se liší dle způsobu jejich kognitivního zpracování (Larkin \& Simon, 1987). Schnotz et al. (2014) v nedávném výzkumu odhalili, že žáci k textovým a obrazovým materiálům přistupují odlišně. Text žáci využívají zejména tehdy, když potřebují získat ucelený přehled o řešeném problému. Textové informace vedou k hlubšímu porozumění významů, a jsou proto vhodné pro vytvoření prvotního mentálního modelu. Naproti tomu obrázky žáci využívají zpravidla jako kognitivní lešení konkretizující text. Mohou sloužit i jako vizuální vodítko (rychlá nápověda), k němuž se žáci vracejí, když potřebují čerpat informace pro řešení určité učební úlohy. Je třeba mít na paměti, že do výzkumu poměrně významně vstupují individuální charakteristiky žáků: předchozí znalosti určitého typu vizuálie, oborová znalost, věk, individuální odlišnosti, např. souvislost se stylem učení se ale nepodařilo prokázat Mayer, 2011: s. 434). ${ }^{4} \mathrm{~V}$ některých případech je lepší, když je přítomna pouze jedna vizuálie. V jiných případech může být užitečné použití jednodušší reprezentace, a to bud' postupně nebo zároveň. V tomto ohledu je nezbytné zkoumat, zda odlišné cílové zaměření učební úlohy může ovlivňovat požadavky na design/tvorbu geografických vizuálií obsažených v edukačních materiálech. Je-li tedy cílem naučit žáky interpretovat graf nebo mapu, požadavky na geografickou vizuálii budou jiné, než když od žáků bude očekávána pouze deklarativní znalost (znalost typu „co“).

Podle Petterssona (1992: s. 110) je kognitivní zpracování vizuálií selektivní. Di̊ležitou roli při rozhodování, jakým informacím budeme věnovat pozornost, hrají

\footnotetext{
${ }^{4}$ Výčet faktorů, které mohou ovlivňovat učení se z obrazového materiálu, zpracovala Havelková (2016). Na straně uživatele jde o jeho předchozí znalosti, dovednosti, gramotnost, věk, kulturní prostředí, vztah k zeměpisu, prostorovou představivost a orientaci, pamět, individuální kognitivní a učební styl či pohlaví. V rámci skupiny vnějších faktorů je třeba vzít v potaz charakter vzdělávání, denní dobu učení, prostředí, motivaci, přítomnost rušivých podnětů, časového limitu či stresorů. Konečně na samotných vizuáliích je třeba zohlednit jejich komplexnost, abstraktnost, grafickou zaplněnost, kompozici, použité vyjadřovací prostředky, grafickou kvalitu a další faktory použitelnosti (názornost, čitelnost, přehlednost, rozlišitelnost ap.) a specifické proměnné (u mapy například měřítko, provedení legendy, orientace vưči světovým stranám ad.).
} 
subjektivní faktory, zejména představy a dosavadní zkušenosti (prvotní dojem) uživatele. Nejdřive dochází k bezprostřednímu vnímání tzv. „povrchových struktur", přičemž jsou zapojovány jednodušší kognitivní procesy. Teprve v případě, že se vizuální reprezentace „potkávají“ s našimi očekáváními, dochází k analytickému zpracovávání vizuální informace, při němž jsou zapojovány složitější kognitivní procesy. Z hlediska koncipování geografických vizuálií se ale jako důležitější jeví zjištění, že uživatelé zaměřují pozornost bezděčně spíše na elementy vizuálií, které jsou pro ně percepčně atraktivní, než informace, které jsou nejvíce relevantní z hlediska obsahu (Lowe, 1999). Výzkumy dále ukazují, že k lepšímu porozumění poskytované informaci také vede tvorba vizuálií (Van Meter, 2001). Ta je zároveň jednou z cest, jak si žáci mohou uvědomit problémy a rizika spojená s chybnou interpretací zobrazovaných skutečností včetně souvisejících problémů a rizik (viz Bresciani \& Eppler, 2015). K obdobným závěrům dospěli v oblasti mapových dovedností také Marada a Hanus (2014).

Mayer (2013: s. 60-66) uvádí, že vizuální typy reprezentací jsou přínosné pro učení, zejména pokud obsahují i krátké objasňující pasáže textu. Rozhodující z hlediska efektivnosti vizuálních reprezentací je však to, do jaké míry dokážou snižovat kognitivní zátěž učícího se jedince. Mayer (2011) a Sweller (2005) a odvoláním na četné výzkumy navrhují při tvorbě vizuálií respektovat následující doporučení (evidence-based practice):

1. Měl by se omezit všechen nadbytečný text a vizuálie.

2. Měl by být zvýrazněn zásadní text a vizuálie.

3. Text by měl být v blízkosti vizuálie (prostorová blízkost vede $\mathrm{k}$ provázanosti).

4. Korespondující text a vizuálie by měly být prezentovány současně (současnost podnětů).

5. Vizuálie by měly být použitelné (čitelnost, názornost, přehlednost ad.).

6. Je nezbytné, aby studovaný materiál měl z pohledu učícího se jedince smysl (smysluplnost).

Ainsworthová na základě zmapování obsáhlého výzkumného pole uvádí, že aktuálně již není př́nosné zkoumat souvislost mezi formou vizuálie a procesem učení (Ainsworth, 2006: s. 184). Těžištěm zájmu výzkumníků by se měly stát specifické charakteristiky jednotlivých vizuálií s cílem aplikovat zjištění o jejich fungování při tvorbě edukačních materiálů. Jinými slovy by měli výzkumníci zaměřit svou pozornost na klíčové charakteristiky vizuálií, jejich analýzu a hodnocení jejich použitelnosti ve vztahu $\mathrm{k}$ předpokládanému výukovému účelu. Co se typů vizuálií týče, nedoporučuje se zkoumat je izolovaně, ale v interakci s ostatními typy vizuálií. Zde je třeba brát zvláštní zřetel nejen k typu vizuálie, ale také k cílovému směřování učební úlohy (resp. vzdělávacímu cíli).

\section{GeOgRAFICKÉ VIZUÁlie JAKO KLÍČOVÉ REPREZENTACE V GEOGRAFICKÉM VZDĚLÁVÁNÍ}

V této části textu se zaměřujeme pouze na oblast statických vizuálií v geografickém vzdělávání. Oblast našeho zájmu jsme zúžili proto, že účelem předkládané přehledové studie je především generovat poznatky využitelné ke zlepšování kvality učebnic a atlasů. 
Kognitivní teorie a další obecné poznatky o učení se z obrazového materiálu představené $\mathrm{v}$ předchozích částech této studie jsou postaveny na předpokladu, že klíčovou proměnnou pro úspěšné učení prostřednictvím vizuálií jsou předchozí znalosti $\mathrm{v}$ určité obsahové doméně a současně znalosti o fungování příslušného typu vizuálií (Mayer, 2011: s. 433). Jedinec musí vědět, jak s využitím reprezentace získat potřebnou obsahově relevantní informaci a jaký typ reprezentace je s ohledem na charakter potřebné informace nejvhodnější. Z uvedeného vyplývá, že interpretace vizuálií je kontextově vázaná aktivita, nebot učicí se jedinec musí rozumět vztahu mezi reprezentací a příslušnou obsahovou doménou (Roth \& Bowen, 2001). To legitimizuje naši snahu zaměřit se primárně na oblast geografického vzdělávání. Pro geografické vzdělávání je typická potřeba zachytit a zprostředkovat mnoho různorodých informací a transformovat je do podoby adekvátní cílovému zaměření učební úlohy a kognitivním možnostem zamýšleného uživatele. Jedinec by měl s využitím vizuálie získat potřebnou obsahově relevantní informaci a zároveň by měl být schopen určit, který typ vizuálie je s ohledem na charakter potřebné informace nejvhodnější. V geografii se například užívají obrázky, grafy a mapy ke znázorňování dat nebo fotografie a obrázky ke znázorňování lidí a míst. Důležité je, aby geografické vizuálie zprostředkovávaly hloubkovou strukturu (podstatu, principy) geografických jevů a procesů a současně směřovaly $\mathrm{k}$ dosažení vzdělávacího cíle. Nevhodně zvolená vizuálie může vést $\mathrm{k}$ tomu, že jedinec přehlédne podstatné informace. $\mathrm{V}$ geografii se např́iklad užívají fotografie, obrázky, mapy a mapám příbuzná zobrazení, schémata, grafy apod. ke znázorňování dat o lidech, místech, krajinách a souvisejících jevech a procesech.

Hlavním smyslem geovizualizace ve vzdělávání je redukce komplexních informací a snižování míry kognitivní zátěže. Vycházíme z předpokladu, že pro potřeby výuky geografie je rozhodující koncipovat vizuální reprezentace tak, aby: a) vycházely z poznatků a doporučení obecných kognitivně psychologických teorií, b) reflektovaly nároky konkrétní učební úlohy a c) zároveň odpovídaly požadavkům a úrovni dosavadních znalostí cílové populace. Každý z uvedených faktorů obsahuje velké množství proměnných, z nichž řadu lze uplatnit obecně, nejen u geografických vizuálií. Ačkoli nemáme k dispozici doménově-specifické teorie, obecné (kognitivně-psychologické) principy pro vytváření vizuálií však umožňují vysvětlovat i fungování geografických vizuálií. Děje se tak ale pouze do určité míry. V momentě, kdy je třeba zjistit, jaké charakteristiky má mít vizuálie, která umožňuje/podporuje hlubší porozumění konkrétního geografického učiva, narážíme na poměrně zásadní nedostatek výzkumů dosud realizovaných v této oblasti. Mírně lepší situace je na poli výzkumů zjištujících efektivitu učení s využitím map (srov. např. Wiegand, 2006; Mrázková, 2013 aj.) nebo leteckých snímků (Svatoňová, 2017).

\subsection{DEFINICE A OPERACIONALIZACE GEOGRAFICKÝCH VIZUÁLIÍ}

Patrně nejzávažnějším výstupem našeho badatelského úsilí je zjištění, že na základě studia odborné pedagogicko-psychologické a geografické literatury nejsme s to identifikovat oborově specifické charakteristiky vizuální geografické informace (ty jsou společné většině vizuálních reprezentací např́ič obory). K operačnímu vymezení geografických vizuálií jsme přistoupili na základě specifického obsahu vizuálie vycházejícího z definice geografie a geografického poznání.

Jak uvádí Gregory (2009: s. 288), je obtížné nalézt mezi různými paradigmaty v geografii shodu v tom, co je jejím předmětem zájmu, nicméně většině prací je společné, že se jedná o „zkoumání toho, jakým způsobem se prostor promítá do 
fungování a výsledků působení společenských a přírodních procesů“. Kulturní obrat v geografii svým důrazem na postdisciplinaritu, procesnost, každodennost, utváření významů a zaměření na jednání aktérů způsobil, že geografický prostor v současnosti zahrnuje celé spektrum prostorů, prostorových aspektů nebo též prostorovostí (Osman \& Matoušek, 2014; Siwek, 2011). Johnston (1986, cit. podle Siwek, 2011) uvádí, že geografický prostor je takový, který se vztahuje k člověku, a primární pro něj je tedy provázanost s člověkem, lidskou společností a jejími aktivitami (působením). Třebaže takové tvrzení více zdůrazňuje předmět zájmu humánní geografie než geografie fyzické, i fyzická geografie studující př́rodní jevy, procesy a zákonitosti, je zkoumá v jejich relaci ke společnosti a k životnímu prostředí člověka. Geografické vizuálie tedy nelze chápat jako neutrální artefakt, nýbrž jako konstrukt zprostředkovávající kulturně a sociálně podmíněný pohled na vybrané geografické jevy. Geografické specifikum v nazírání prostoru reprezentuje měřítko/řádovost (scale) (viz např. Leitner \& Miller, 2007; Sheppard \& McMaster, 2004). Jedná se o gnozeologický přístup vyčleňování a rozlišování různých hierarchických úrovní zemského povrchu, entit a vztahů na něm se nacházejících, od jedince a lokality, mikroregionu přes větší (mezoregionální), makroregionální až po globální úroveň. S uvedeným souvisí akcent geografie na definování regionů a ohraničování prostoru (blíže viz např. Claval, 1998; Paasi, 2004 aj.), které mohou být konstruovány jednáním aktérů, v myslích jedinců či v konsenzu společnosti.

Z toho lze usuzovat, že geografická vizuálie představuje libovolnou vizuální reprezentaci:

(a) organizace (uspořádání) geografických systémů a objektů jakožto relativně komplexních celků v prostoru, v níž jsou znázorněny vnější vztahy (a probíhající procesy) mezi jednotlivými částmi (elementy) těchto celků, příp. jejich příčiny a důsledky (Hampl, 1998), př́kladem může být schéma všeobecného oběhu atmosféry;

(b) prostorové/geografické diferenciace libovolných jevů nebo procesů v přírodním a sociálním prostředí (či v obou zároveň) např́íč různými řádovostními/měřítkovými úrovněmi (např. globální, regionální, lokální) (Gregory, 2009), př́íkladem mohou být tematické mapy lokalizace průmyslových odvětví a oblastí;

(c) podoby, charakteristiky a ohraničení prostoru/území (z perspektiv různých aktérů) (Giddens, 1979; Lefebvre, 1991; Paasi, 1986), př́́kladem jsou fotografie krajiny či obecně-zeměpisná mapa ve školním atlase.

V obecné rovině geografická vizuálie funguje jako grafická reprezentace určitého fenoménu, lokality nebo procesu, která podporuje rychlejší kognitivní zpracování prostorových aspektů (vizuální) geografické informace prostřednictvím rychlejšího a přesnějšího usměrňování pozornosti na relevantní data. ${ }^{5} \mathrm{Z}$ uvedeného vymezení vyplývá pro geografické vzdělávání typická potřeba zachytit a zprostředkovat mnoho různorodých prostorových dat a transformovat je do podoby adekvátní cílovému zaměření učební úlohy a kognitivním možnostem zamýšleného uživatele (Skupin \& Esperbé, 2008: s. 160). Informací o tom, na základě jakých kritérií hodnotit kvalitu geografických vizuálií, je však nedostatek.

Ve výuce zeměpisu/geografie se mimoto můžeme setkat také s reprezentacemi, které nejsou primárně geografické (viz definice výše), ale náleží primárně k jiným

\footnotetext{
${ }^{5}$ Zde je třeba rozlišovat mezi: 1) geografickým porozuměním, jež staví na mentálních reprezentacích geografického prostoru a fenoménů s cílem porozumět jejich podstatě a 2 ) prostorovým vnímáním, které zahrnuje kognitivní procesy související s porozuměním a znovu vybavováním prostorových informací.
} 
vědním disciplínám, např. vývoj počtu vyrobených automobilů v Cesku od roku 1989. Jejich užití však může v souvislosti s dalšími informacemi nabývat geografický rozměr, v tomto př́padě např. potenciál regionálního rozvoje. Jako př́klad podobné reprezentace, ale primárně vycházející z geografie, by byl např. graf počtu vyrobených automobili̊ v jednotlivých evropských státech (druhá z výše zmíněných skupin - geografická diferenciace jevu).

\subsection{SPECIFICKÉ FUNKCE GEOGRAFICKÝCH VIZUÁLIÍ}

Podle Dodge, McDerbyové a Turnera (2008: s. 3-4) lze poměrně bohaté spektrum funkcí geografických vizuálií utřídit do tří epistemologických oblastí odkazujících k jednotlivým úrovním geografického poznávání:

1. Nazíráni (looking) - jedná se o geografické vizuálie vytvořené dle daných kritérií (např. zeměpisná sít). Slouží ke znázorňování geografických jevů, zdůrazňuje jejich prostorové aspekty a umožňují základní orientaci a jednoduchou interakci s geografickými daty.

2. Hledání/zjištování (querying) - jde o geografické vizuálie s významným informačním př́inosem. Organizují komplexní geografická data a zpřehledňují relevantní informace potřebné $\mathrm{k}$ interakci s určitým geografickým problémem (výukovým úkolem). Napomáhají kognitivnímu propojování mezi různými úrovněmi zobrazení téhož geografického fenoménu. Nabízejí uživateli více prostoru, pokud jde o individuální kognitivní preference a potřeby.

3. Objevováni (questioning) - geografické vizuálie zprostředkovávající vhled k podstatě určitého geografického jevu. Efektivně znázorňuje změnu a vývoj geografických jevů. Umožňuje rozbor, interagování, ověřování zobrazovaných informací. Zprostředkovávají data k zodpovězení „co“ a „proč“ otázek týkajících se geografických jevů. Uživatel má kontrolu nad zobrazením, měřítkem, projekcí zobrazovaných dat. ${ }^{6}$

\subsection{HLEDÁNí OBOROVĚSPECIFICKÝCH CHARAKTERISTIK GEOGRAFICKÝCH VIZUÁLIÍ}

Syntéza teoretických poznatků (viz Swienty et al., 2008: s. 232) vede k vyvození konkrétních (základních) kvalit geografické vizuálie: a) jednoduchost - redukce komplexnosti (generalizace) zobrazovaného jevu může napomáhat efektivnějšímu kognitivnímu zpracování; ${ }^{7}$ b) výstižnost - zdůraznění nejdůležitějších informací pomocí jednoduchých, pozornost usměrňujících elementů; c) vizuální hierarchie - organizace a strukturování zobrazovaných informací pomocí vrstev; více relevantní informace jsou zdůrazněny, zatímco méně relevantní informace mohou být upozaděny, což napomáhá efektivnímu kognitivnímu zpracovávání.

Vedle snižování komplexity geografických informací by však geografické vizuálie měly motivovat i vést $\mathrm{k}$ objevování nových poznatků, např. prostřednictvím podpory analytického uvažování a argumentace, případně zprostředkováním syntézy

\footnotetext{
${ }^{6}$ Jedná se v podstatě o analogické funkce reprezentací zmiňované Ainsworthovou (1999, viz výše).

${ }^{7} \mathrm{~S}$ tím pracuje koncept geografického, resp. kartografického modelování a v rámci něj (kartografická) generalizace reality (tj. nelze mapovat v měřítku $1: 1$ a vždy je třeba provádět výběr, zjednodušení, zdůraznění a slučování kategorií reality). Zmíněný poznatek také implikuje požadavek, aby se v učebnicích zeměpisu vyskytovaly v mnohem menší míře fotografie. Výzkumy ukazují, že fotografie v českých učebnicích zeměpisu výrazně dominují (Janko, 2015).
} 
informací (Swienty et al., 2008: s. 229). Zmínění autoři na základě způsobů kognitivního zpracování vizuální geografické informace vymezují 21 konkrétních vlastností geografických vizuálií. Konkrétně se jedná o kvality jako kontura (velikost), tvar, barevnost, rozlišení, jemnost (detailnost), transparentnost (jasnost). Podstatným atributem geografických vizuálií je barevnost (adekvátní volba barev). Volba barvy a její zapracování do geografických vizuálií může podstatně ovlivnit, jak jsou zobrazované informace vnímány. Jednotlivé elementy geografických vizuálií mohou být pomocí barvy zdůrazněny nebo naopak upozaděny. Barva může sloužit i pro zvýraznění hloubky (perspektivy), může zaměřovat (resp. omezovat) pozornost jedince na konkrétní aspekty (např. jevy, území, hranice). Naopak neadekvátní volby barvy může vést $\mathrm{k}$ matení jedince a ztěžovat mu tak porozumění (podrobněji viz Bláha, 2010).

Důležitou funkcí geografických vizuálií je napomáhat při kognitivní systemizaci geografických jevů a procesů. Lloyd, Hodgson a Stokesová (2002) zjištovali, do jaké míry může být klasifikace geografických jevů (využití krajiny) ovlivněna kvalitami geografických vizuálií (leteckých fotografií). Konkrétně analyzovali, jak se liší schopnost klasifikovat využití/pokryv krajiny $\mathrm{v}$ závislosti na velikosti a abstraktnosti vizuálie a také $\mathrm{s}$ přihlédnutím $\mathrm{k}$ předchozím zkušenostem respondentů $\mathrm{s}$ různými typy vizuálií. Ukázalo se, že velikost vizuálie může napomáhat k přesnějšímu kognitivnímu zpracování. Dále respondenti dokázali poměrně rychle, přesně a sebejistě klasifikovat geografické jevy obecnější povahy (typy krajiny), ve srovnání s jevy více konkrétními (ekonomické aktivity v krajině). K lepším výsledkům dospěli respondenti, kteří měli možnost pracovat s typy vizuálií, s nimiž již mají zkušenost, anebo pokud s vizuáliemi pracují pod dohledem zkušenějšího kolegy. V tematicky obdobně koncipovaném výzkumu Priestnall a Hampson (2008: s. 245) zjištovali, které charakteristiky geografických vizuálií jsou pro žáky důležité při hodnocení míry relevantnosti (věrnosti/názornosti) vizuálie vzhledem k reálnému geografickému objektu (informační kapacity/přesnosti). Autoři identifikovali 6 základních faktorů, které jsou z pohledu žáků při práci s geografickými vizuáliemi důležité: 1) měřítko a míra komplexnosti, 2) věrohodnost kompozice a rozmístění určujících znaků, 3) technické parametry/možnosti záznamového zařízení, 4) prostorový kontext a dřivější zkušenosti, 5) celkový dojem/atmosféra, 6) informační hodnota (dostatek indicií) umožňující ověření vlastní představy/mentálního modelu zobrazovaného jevu.

Důležitou součástí didakticky kvalitně zpracovaných geografických vizuálií může být i určitá míra nejednoznačnosti při zprostředkovávání geografických jevů (prostorová, časová, atribuční). Podle Deitrickové a Edsalla (2008: s. 278-279) jde o to, že i když geografické vizuálie znázorňují reálné jevy, jsou vždy jen aproximací komplexní geografické reality. V principu tedy obsahují určitou míru nejednoznačnosti/nepřesnosti (uncertainty). ${ }^{8}$ Velká míra nejednoznačností vede k rozmělňování pozornosti, a v důsledku k nepřesnému porozumění (Halverson, 1968: s. 10-16). Na druhou stranu přiměřená míra nejednoznačnosti vedená snahou o dosažení náročnějšího vzdělávacího cíle může působit pozitivně a motivovat $\mathrm{k}$ intenzivnějšímu kognitivnímu interagování se zobrazovaným jevem (odvozování významů) a v konečném důsledku také k hlubšímu porozumění a přesnějšímu rozhodování (srov. Davis \& Keller, 1997).

\footnotetext{
${ }^{8}$ Míra nejednoznačnosti (uncertainty) se u různých geografických vizuálií může lišit v závislosti na vlastnostech jako preciznost zpracování, logická konsistence a kompletnost prezentovaných dat, lineárnost, míra kontroly nad znázorňovanými informacemi, či přiléhavost ke konkrétnímu účelu. Je možné zde spatřovat analogii s didaktickým využíváním tzv. neúplně strukturovaných (nebo také neúplně definovaných) problémů (podrobněji viz Češková, 2017).
} 
Geografické vizuálie jsou ve školní geografii často využívány k zobrazování prostorových aspektů geografických jevů a procesů, časové aspekty jsou zobrazovány méně. Proto je prostřednictvím geografických vizuálií zobrazován spíše stav než vývoj geografické reality. To se následně promítá do dominantního zastoupení určitých typů geografických vizuálií např. v učebnicích (Harrower \& Fabrikant, 2008; Janko, 2015). Na tomto místě považujeme za vhodné upozornit na výukový potenciál znázorňování časové dimenze geografických jevů a procesů. Základními možnostmi, jak pracovat $\mathrm{s}$ časem $\mathrm{v}$ geografických vizuáliích, představují pojetí času jako změny či vývoje geografického jevu v prostoru (angl. spatial time), či změna tempa, intenzity nebo délky trvání geografického jevu (angl. temporal time). ${ }^{9}$ Je pravděpodobné, že více možností pro utváření geografických znalostí a dovedností související s časovou dimenzí prostorových jevů, nabízí zejména dynamické formy geografických vizuálí (Vít \& Bláha, 2012; Harrower \& Fabrikant, 2008: s. 53; Kraak, 2008).

\section{Diskuse A ZÁVĚR}

Naše badatelské úsilí je možné shrnout do několika tezí, které současně poskytují odpovědi na položené výzkumné otázky. Ke zkoumání procesu učení se z obrazového materiálu v kontextu geografického vzdělávání autoři nejčastěji vycházejí z následujících teorií: teorie duálního kódování, kognitivní teorie multimediálního učení, teorie kognitivní zátěže a teorie obrazu. Zmiňované teorie jsou založeny na rozlišování senzorických kanálů (např. sluchový/vizuální) anebo různorodých modů reprezentací (např. textové/obrazové) a také předpokladu omezené kapacity pracovní paměti učícího se jedince. Dospěli jsme ke zjištění, že na základě studia odborné literatury nejsme s to operacionalizovat geografické vizuálie a současně identifikovat oborově specifické charakteristiky a funkce geografických vizuálií (ty jsou společné většině vizuálních reprezentací např́íč obory). K operačnímu vymezení geografických vizuálií jsme využili konsenzuální definici geografie jako vědecké disciplíny a geografického poznání. Geografická vizuálie dle našeho názoru funguje jako grafická reprezentace určitého fenoménu, lokality či procesu, která podporuje rychlejší kognitivní zpracování prostorových aspektů zobrazované reality.

Aktuálně již není přínosné zkoumat souvislost mezi formou reprezentace a procesem učení (Ainsworth, 2006: s. 184). Skutečnost, že využití více modů reprezentací zvyšuje efektivitu učení, byla již mnohokrát prokázána. Těžištěm zájmu výzkumníků by se měly stát konkrétní konstrukční charakteristiky jednotlivých forem reprezentací s cílem aplikovat výsledná zjištění při tvorbě edukačních materiálo̊. Je třeba brát zvláštní zřetel nejen k typu reprezentace, ale také k typu související učební úlohy/cíli vzdělávání. V tomto ohledu je nezbytné zkoumat, zda odlišné cílové zaměření učební úlohy může ovlivňovat požadavky na design/tvorbu vizuálních geografických informací obsažených ve výukových materiálech. Informací o tom, na základě kterých indicií hodnotit adekvátnost reprezentací, např. vzhledem ke zvolené úloze, je však minimum. Do výzkumu poměrně významně vstupují individuální charakteristiky žáků: předchozí znalosti určitého typu reprezentace, oborová znalost, věk, individuální odlišnosti apod. (podrobněji MacEachren et al., 2004). Efektivní využití vizuální geografické informace ve vzdělávání vyžaduje, aby žák disponoval: a) znalostí systému reprezentací reality v geografii, b) dovedností poznání reálného a reprezentovaného objektu a c) schopností zasazení získaných informací do kontextu

\footnotetext{
${ }^{9}$ Haggett (1990) rozlišuje čtyři typy času, které reprezentují různé vzorce a změny geografických jevů a procesů: konstanty, trendy, cykly, posuny.
} 
geografických znalostí. Přitom mohou pak nastávat chyby v neznalosti systému, neznalosti samotného objektu apod.

Jonesová a kol. (2009: s. 1080-1081) upozorňují, že při tvorbě a zkoumání vizuálií je nutné přistoupit ke změně perspektiv. Současný př́istup ke tvorbě geografických vizuálií totiž dle zmíněných autorů vychází především z technologických možností geovizualizace a neumožňuje dostatečně citlivě zohledňovat nároky na vizuálie z hlediska konkrétních učebních cílů, resp. procesu utváření znalostí. Problematické je množství funkcí, př́lišná interaktivita nebo nedostatečná uživatelská zpětná vazba. Žáci/uživatelé se tak mnohdy soustředí více na formu vizuálie a manipulaci s ní, než na poznatky/informace v ní obsažené. Rozvoj technologických možností vyústil v nutnost začít rozlišovat mezi koncepty funkčnosti a použitelnosti geografických vizuálií.

Pokud bychom měli v závěru této studie formulovat doporučení pro teorii a praxi, zřejmě by mělo být řečeno následující: je pravděpodobné, že žádná oborově specifická teorie didaktického využití geografických vizuálií neexistuje. Vizuálie je třeba tvořit a následně je využívat s oporou ve vybraných kognitivněpsychologických teoriích a současně s přihlédnutím k cílům vzdělávání zrcadlícím předmět zkoumání a metody příslušného oboru.

\section{PoDĚKOVÁNí}

Příspěvek je výstupem řešení projektu GA ČR Vizuální geografická informace a její role v geografickém vzděláváni (GA16-01003S). Autoři děkují za poskytnutou podporu.

\section{LITERATURA}

Ainsworth, S. (1999). The functions of multiple representations. Computers and Education, 33(2-3), 131-152.

Ainsworth, S. (2006). DeFT: A conceptual framework for considering learning with multiple representations. Learning and Instruction, 16(3), 183-198.

Aumont, J. (2011). L'Image. Paris: Armand Colin.

Ballstaedt, S.P. (1997). Wissensvermittlung: Die Gestaltung von Lernmaterial. Weinheim: Beltz.

Benedek, A. \& Nyíri, K. (2012). The iconic turn in education. Frankfurt am Main: Peter Lang.

Bertin, J. (1967). Sémiologie graphique: Les diagrammes - les réseaux - les cartes. Paris: Mouton.

Bláha, J. D. 2010. Various ways of assessment of cartographic works. In G. Gartner \& F. Ortag (Eds.), Cartography in Central and Eastern Europe. Lecture notes in geoinformation and cartography (211-229). Berlin, Heidelberg: Springer.

Bresciani, S. \& Eppler, M. J. (2015). The pitfalls of visual representations. Sage Open, $5(4), 1-14$.

Češková, T. (2017). Výukové situace rozvíjející kompetenci k řešení problémů: teoretický model jako východisko pro jejich analýzu. Pedagogika, 66(5), 530-548. 
Chi, M. T., Feltovich, P. J. \& Glaser, R. (1981). Categorization and representation of physics problems by experts and novices. Cognitive Science, 5(2), 121-152.

Claval, P. (1998). An introduction to regional geography. Oxford: Wiley-Blackwell.

Davies, P. (2000). The relevance of systematic reviews to educational policy and practice. Oxford Review of Education, 26(3-4), 365-378.

Davis, T. J. \& Keller, C.P. (1997). Modelling uncertainty in natural resource analysis using fuzzy sets and Monte Carlo simulation: slope stability prediction. International Journal of Geographical Information Science, 11(5), 409-434.

de Saussure, F. (1916). Cours de linguistique générale. Paris: Payot.

Deitrick, S. \& Edsall, R. (2008). Making uncertainty usable: Approaches for visualizing uncertainty information. In M. Dodge, M. McDerby \& M. Turner (Eds.), Geographic visualization. Concepts, tools and applications (277-292). Chichester: Wiley \& Sons.

Dodge, M., McDerby, M. \& Turner, M. (2008). The power of geographical visualuzations. In M. Dodge, M. McDerby \& M. Turner (Eds.), Geographic visualization. Concepts, tools and applications (1-10). Chichester: Wiley \& Sons.

Eco, U. (1976). Theory of semiotics. Bloomington: Indiana University Press.

Gates, S. (2004): Visual literacy in science and its importance to pupils and teachers. In A. Peacock \& A. Cleghorn (Eds.), Missing the meaning (223-237). New York: Palgrave Macmillan.

Giddens, A. (1979). Central problems in social theory: Action, structure and contradiction in social analysis. Berkeley: University of California Press.

Gregory, D. (2009). Geography. In D. Gregory, et al., The dictionary of human geography (287-295). Malden: Blackwell.

Haggett, P. (1990). The geographer's art. Camebridge: Blackwell.

Halverson, L. H. (1968). Geography via pictures. Do it this way. Illinois: National Council for Geographic Education.

Hampl, M. (1998). Realita, společnost a geografická organizace: hledání integrálního řádu. Praha: Karolinum.

Harrower, M. \& Fabrikant, S. (2008). The role of map animation for geographic visualization. In M. Dodge, M. McDerby \& M. Turner (Eds.), Geographic visualization. Concepts, tools and applications (49-65). Chichester: Wiley \& Sons.

Havelková, L. (2016). Vliv kartografické vyjadřovací metody na úroveň mapových dovedností žáků. Diplomová práce. Praha: PřF UK.

Hübelová, D., Najvarová, V. \& Chárová, D. (2008). Uplatnění didaktických prostředků a médií ve výuce zeměpisu. In P. Knecht \& T. Janík (Eds.), Učebnice z pohledu pedagogického výzkumu (147-163). Brno: Paido.

Janko, T. (2012). Nonverbální prvky v učebnicích zeměpisu jako nástroj didaktické transformace. Brno: MU.

Janko, T. (2015). Srovnávací analýza typů nonverbálních prvků v současných českých a německých učebnicích školní geografie. Pedagogická orientace, 25(2), 225-248.

Jewitt, C. (2008). The visual in learning and creativity: A review of the literature. London: Creative Partnership. 
Johnston, R. J. (1986). Philosophy and human geography: An introduction to contemporary approaches. London: Edward Arnold.

Jones, C. E., Haklay, M., Griffiths, S. \& Vaughan, L. (2009). A less is more approach to geovisualization - enhancing knowledge construction across multidisciplinary teams. International Journal of Geographical Information Science, 23(8), 1077-1093.

Koláčný, A. (1969). Cartographic information - a fundamental concept and term in modern cartography. The Cartographic Journal, 6(1), 47-49.

Kraak, M. J. (2008). Visualization and time. New opportunities for the space-time cube. In M. Dodge, M. McDerby \& M. Turner (Eds.), Geographic visualization. Concepts, tools and applications (293-306). Chichester: Wiley \& Sons.

Larkin, J. H. \& Simon, H. A. (1987). Why a diagram is (sometimes) worth ten thousand words. Cognitive Science, 11(1), 65-99.

Lefebvre, H. (1991). The production of space. Oxford: Blackwell.

Leitner, H. \& Miller, B. (2007). Scale and the limitations of ontological debate: A commentary on Marston, Jones and Woodward. Transactions of the Institute of British Geographers, 32(1), 116-125.

Lloyd, R., Hodgson, M. E. \& Stokes, A. (2002). Visual categorization with aerial photographs. Annals of the Association of American Geographers, 92(2), 241-266.

Lowe, R.K. (1999). Extracting information from an animation during complex visual learning. European Journal of Psychology of Education, 14(2), 225-244.

MacEachren, A. M., Gahegan, M., Pike, W., Brewer, I., Cai, G., Lengerich, E. \& Hardistry, F. (2004). Geovisualization for knowledge construction and decision support. Computer Graphics and Applications IEEE, 24(1), 13-17.

Marada, M. \& Hanus, M. (2014). Mapové dovednosti: vymezení a výzkum. Geografie, $119(4), 406-422$.

Mareš, J. (2013a). Pedagogická psychologie. Praha: Portál.

Mareš, J. (2013b). Přehledové studie: jejich typologie, funkce a způsob vytváření. Pedagogická orientace, 23(4), 427-454.

Mayer, R.E. (1997). Multimedia learning: Are we asking the right questions? Educational Psychologist, 32(1), 1-19.

Mayer, R. E. (2011). Instruction based on visualisations. In R. E. Mayer \& P. A. Alexander (Eds.), Handbook of research on learning and instruction (427-445). New York: Routledge.

Mayer, R.E. (2013). Fostering learning with visual displays. In G. Schraw, M. T. McCrudden \& D. Robinson (Eds.), Learning through visual displays (47-73). Charlotte: Information Age Publishing.

Mayer, R. E. (2014). Cognitive theory of multimedia learning. In R. E. Mayer (Ed.), Multimedia learning (43-71). New York: Cambridge.

McTigue, E. M. \& Coleman, J. M. (2013). Theory, practice, and challenges for teaching visual literacy in science. In K. D. Finson \& J. E. Pedersen (Eds.), Visual data and their use in science education (281-307). Charlotte: Information Age Publishing.

Mrázková, K. (2013). Kartografické dovednosti ve výuce zeměpisu (Disertační práce). Brno: PdF MU. 
Osman, R. \& Matoušek, R. (2014). Úvod obratem. In R. Matoušek \& R. Osman (Eds.), Prostor(y) geografie (9-18). Praha: Karolinum.

Paasi, A. (1986): The institutionalization of regions: a theoretical framework for understanding the emergence of regions and the constitution of regional identity. Fennia, 164(1), 105-146.

Paasi, A. (2004). Place and region: Looking through the prism of scale. Progress in Human Geography, 28(4), 536-564.

Paivio, A. (1971). Imagery and mental processes. New York: Holt, Rinehart and Winston.

Paivio, A. (2014). Mind and its evolution: A dual coding theoretical approach. New York: Psychology Press.

Peirce, Ch. S. (1997). Sémiotika. Praha: Karolinum.

Pettersson, R. (1992). The use of visuals in oral representations. Educational Technology Research and Development, 40(2), 109-116.

Priestnall, G. \& Hampson, D. (2008). Landscape visualization: Science and art. In M. Dodge, M. McDerby \& M. Turner (Eds.), Geographic visualization. Concepts, tools and applications (241-258). Chichester: Wiley \& Sons.

Radinsky, J., Leimberer, J. M. \& Rodriguez, C. (2013). Learning to do geospatial data visualizations in science classrooms. In K. D. Finson \& J. E. Pedersen (Eds.), Visual data and their use in science education (239-260). Charlotte: IAP Publishing.

Rose, G. (1994). Teaching visualized geographies: Towards a methodology for the interpretation of visual materials. Journal of Geography in Higher Education, 20(3), 281-294.

Rose, G. (2007). Visual Methodologies: An introduction to the interpretation of visual materials. London: SAGE.

Roth, W. M. \& Bowen, G. M. (2001). Professionals read graphs: A semiotic analysis. Journal for Research in Mathematics Education, 32, 159-194.

Sadoski, M. \& Paivio, A. (2001). Imagery and text: A dual coding theory of reading and writing. Mahwah: Lawrence Erlbaum Associates.

Schnotz, W. (2002). Commentary - Towards an integrated view of learning from text and visual displays. Educational Psychology Review, 14(1), 101-120.

Schnotz, W. (2014). Integrated model of text and picture comprehension. In R. E. Mayer (Ed.), Multimedia learning (72-103). New York: Cambridge

Schnotz, W. \& Bannert, M. (2003). Construction and interference in learning from multiple representation. Learning and Instruction, 13(2) 141-156.

Schnotz, W., Ludewig, U., Ullrich, M., Horz, H., McElvany, N. \& Baumert, J. (2014). Strategy shifts during learning from texts and pictures. Journal of Educational Psychology, 106(4), 974-989.

Sheppard, E. \& McMaster, R. B. (Eds.). (2004). Scale and geographic inquiry: Nature, society and method. Oxford: Blackwell.

Siwek, T. (2011). Percepce geografického prostoru. Praha: ČGS.

Skupin, A. \& Esperbé, A. (2008). Towards high-resolution self-organizing maps of geographic features. In M. Dodge, M. McDerby \& M. Turner (Eds.), Geographic visualization. Concepts, tools and applications (49-65). Chichester: Wiley \& Sons. 
Spiro, R. J. \& Jehng, J. C. (1990). Cognitive flexibility and hypertext: Theory and technology for nonlinear and multi-dimensional traversal of complex subject matter. In D. Nix \& R. J. Spiro (Eds.), Cognition, education and multi-media: Exploring ideas in high technology (163-205). Hillsdale: LEA.

Svatoňová, H. (2017). Reading satellite images, aerial photos and maps: Development of cartographic and visual literacy. In P. Karvánková, D. Popjaková, M. Vančura \& J. Mládek (Eds.), Current Topics in Czech and Central European Geography Education (187-208). Cham: Springer.

Sweller, J. (1988). Cognitive load during problem solving: Effects on learning. Cognitive Science, 12, 257-285.

Sweller, J. (2005). Implications of cognitive load theory for multimedia learning. In R. Mayer (Ed.), The Cambridge handbook of multimedia learning (19-30). Cambridge: Cambridge University Press.

Swienty, O., Reichenbacher, T., Reppermund, S. \& Zihl, J. (2008). The role of relevance and cognition in attention-guiding geovisualisation. The Cartographic Journal, 45(3), $227-238$.

Taussig, M. (2011). I swear I saw this: Drawings in fieldwork notebooks, namely my own. Chicago: University of Chicago Press.

Unwin, D. J. (2008). Encounters with geovisualization. In M. Dodge, M. McDerby \& M. Turner (Eds.). Geographic visualization. Concepts, tools and applications (xi-xvi). Chichester: Wiley \& Sons.

Van Meter, P. (2001). Drawing construction as a strategy for learning from text. Journal of Educational Psychology, 93(1), 129-140.

Vít, L. \& Bláha, J.D. (2012). Study of the user friendliness of temporal legends in animated maps. AUC Geographica, 47(2), 53-61.

Wainer, H. (1992). Understanding graphs and tables. Educational Researcher, 21(1), $14-23$.

Wiegand, P. (2006). Learning and teaching with maps. London: Routledge.

Wooldridge, S. W. \& East, W. G. (1951). The spirit \& purpose of geography. London: Hutchinson.

TOMÁŠ JANKO, tjanko83@gmail.com

PETR KNECHT, knecht@ped.muni.cz

Masarykova univerzita, Pedagogická fakulta

Institut výzkumu školního vzdělávání

Pořičí 31, 60300 Brno, Česká republika

Silvie RITA KuČEROVÁ, silvie.kucerova@ujep.cz

JAN DANIEL BLÁHA, jd@jackdaniel.cz

Univerzita J. E. Purkyně v Ústí nad Labem, Př́rodovědecká fakulta

Katedra geografie

České mládeže 8, 40096 Ústí nad Labem, Česká republika 